\title{
HUBUNGAN KONSEP DIRI DENGAN HASIL BELAJAR BIOLOGI SISWA KELAS VII MTS UNIT SEKOLAH BARU (USB) SAGULUNG BATAM
}

\section{THE CORRELATION BETWEEN SELF-CONCEPT AND STUDENTS' OUTCOMES ON LEARNING BIOLOGY AT CLASS VII MTS USB BATAM}

\author{
Haryanti $^{1}$, Rahmi $^{2 *}$, Fauziah Syamsi ${ }^{3}$ \\ ${ }^{123}$ Program Studi Pendidikan Biologi, FKIP, Universitas Riau Kepulauan, Batam \\ *Korespondensi: rahmisikumbang @gmail.com
}

\begin{abstract}
Abstrak
Tujuan dari penelitian ini adalah untuk mengetahui hubungan antara konsep diri dengan hasil biologi belajar siswa kelas VII (tujuh) di MTS Unit Sekolah Baru (USB) Sagulung Batam tahun akademik 2013/2014. Sampel penelitian adalah semua siswa dari siswa kelas VII dengan pengumpulan data dengan cara observasi, wawancara, angket, dan dokumentasi. Metode observasi digunakan untuk memperoleh data tentang kondisi MTs USB, wawancara digunakan untuk mendapatkan informasi tentang Kriteria kelengkapan Minimum (KKM) yang dikenakan dan untuk mendapatkan informasi tentang kegiatan dan masalah hasil belajar dalam rangka mendukung informasi dalam konsep diri siswa untuk subjek Biologi serta Kuesioner digunakan untuk mengumpulkan data variabel konsep diri, dokumentasi digunakan untuk mengumpulkan data tentang hasil belajar Biologi. Uji hipotesis menggunakan pendekatan korelasi sederhana. Berdasarkan penelitian ini nilai korelasi $r=0,246$ atau 24,6\% sehingga dapat disimpulkan bahwa tidak ada hubungan positif antara konsep diri dan hasil belajar biologi siswa kelas VII MTs Unit Sekolah Baru Sagulung Batam.
\end{abstract}

Kata Kunci: Konsepsi diri, Hasil belajar, Korelasi.

\begin{abstract}
The purpose of this study was to determine the correlation between self-concept and students' results on learning biology at class VII (seven) MTS New School Unit (USB) Sagulung, Batam, academic year 2013/2014. The samples were all students of class VII. Data were collected by doing observation, interviews, questionnaires, and documentation. Observation method was used to obtain data about MTs USB condition, interview was used to gathe information about charged minimum completeness criteria (KKM) and to gather information about the activities and learning outcomes problems, in order to support information about students self-concept on Biology subject, and questionnaire was used to collect the data of self-concept variable, and documentation used to collect the data of learning outcomes of Biologysubject. Test the hypothesis usied a simple correlation approach. Based on this study, the correlation value $r=0.246$, or $24.6 \%$, so it can be concluded that there was no positive correlation between self-concept and biology learning outcomes at class VII MTs New School Unit Sagulung, Batam
\end{abstract}

Keyword : Self-Concept, Learning Outcomes of Biology, Correlation.

\section{PENDAHULUAN}

Pendidikan merupakan upaya untuk membantu perkembangan siswa, sebagai makhluk individu dan makhluk sosial, sehingga dia dapat hidup secara layak dalam kehidupannya. Setiap usaha yang dilakukan untuk mengubah perilaku yang diinginkan 
sesuai dengan nilai-nilai dan norma yang berlaku, adalah untuk dapat mencapai perkembangan intelektual yang maksimal, kepribadiannya pun akan terbentuk dengan wajar, mencerminkan sifat-sifat kejujuran, kebenaran, dan tanggung jawab supaya dapat menjadi anggota masyarakat yang baik.

Peningkatan mutu pendidikan merupakan prioritas utama dalam upaya mencerdaskan kehidupan bangsa sehingga diperlukan manusia yang utuh, yaitu manusia yang tidak hanya memiliki pengetahuan dan keterampilan akan tetapi mempunyai kemampuan untuk berfikir rasional kritis dan kreatif. Sikap kritis dan cara ingin maju merupakan sifat ilmiah yang dimiliki oleh manusia. Sifat ini akan menjadi motivator bagi seseorang untuk terus menambah pengetahuan.

Di dalam proses belajar guru memberi dorongan, semangat atau motivasi belajar pada siswa. Kesadaran siswa untuk belajar sangat erat hubungannya dengan konsep diri atau biasa diartikan sebagai cara pandang seseorang terhadap diri mereka sendiri. Penilaian objektif terhadap diri sendiri sangat mempengaruhi kesadaran tentang siapa mereka dengan segala kekurangan dan kelebihannya, melalui kesadaran ini siswa akan lebih mudah untuk menentukan sikap dan perilaku yang harus mereka ambil sesuai dengan gambaran diri mereka dan untuk mencapai tujuan yang ingin mereka capai.

Konsep diri yang positif akan menentukan tingkah laku seseorang sehingga dapat menempatkan diri sesuai dengan gambaran yang siswa buat tentang dirinya. Dalam perilaku belajar, konsep diri positif mendorong seseorang untuk mengenal siapa dirinya dan apa yang harus dilakukannya sebagai seorang siswa. Kesadaran ini nantinya akan membuat siswa lebih termotivasi untuk mencapai keinginan atau cita-citanya dan memiliki konsistensi dalam mewujudkannya.

Berawal dari Program Praktek Pengalaman Lapangan (PPL) di MTs Unit sekolah Baru Sagulung Batam peneliti mendapatkan banyak kesan mengajar yaitu kesan dalam keantusiasan dan perhatian siswa pada pembelajaran Biologi, sebagian siswa masih ada yang mengalami kesulitan dalam menerima dan mempelajari materi pelajaran Biologi, masih banyak siswa yang tidak tertarik, tidak menyukai pelajaran Biologi, dan pelajaran berpusat pada guru, siswa bersifat pasif, serta sering kali mengakibatkan peserta didik merasa jenuh sehingga materi yang disampaikan guru di sekolah tidak dikuasai dengan baik dan berdampak rendahnya hasil belajar Biologi siswa. Rendahnya hasil belajar siswa kelas VII MTs dapat dilihat dari hasil ujian siswa pada semester ganjil tahun pelajaran 
2013/2014. Selain itu masih dijumpai siswa yang memiliki konsep diri negatif. dibuktikan dengan masih adanya siswa yang belum dapat mengenali dirinya sehingga sulit untuk menerima segala kelebihan dan kekurangan yang ada pada dirinya. Berdasarkan latar belakang masalah di atas terkait penelitian tentang hubungan konsep diri dengan hasil belajar Biologi siswa di kelas VII MTs Unit Sekolah Baru Sagulung Batam Tahun Pelajaran 2013/2014. Penelitian ini dilakukan untuk mencapai tujuan yaitu untuk mengetahui apakah terdapat hubungan antara konsep diri terhadap hasil belajar Biologi siswa di kelas VII MTs Unit Sekolah Baru Sagulung Batam.

\section{METODOLOGI}

Dalam penelitian ini, populasi adalah seluruh siswa MTs Unit Sekolah Baru Sagulung Batam, sedangkan populasi terjangkaunya adalah seluruh siswa kelas VII MTs yang terdiri 4 kelas. Teknik analisis data dalam penelitian ini menggunakan; a) statistik deskriptif yakni menyajikan data berupa banyaknya sampel, jumlah nilai, rata-rata nilai, median, modus, variansi, dan standar deviasi; b) analisis prasyarat melakukan pengujian hipotesis dilakukan uji normalitas, Uji normalitas data dilakukan untuk melihat sebaran data hasil penelitian berdistribusi normal atau tidak, uji normalitas menggunakan chi kuadrat; dan c) analisis korelasi yakni menemukan bilangan koefisien adalah bilangan yang menyatakan kekuatan hubungan antara dua variabel atau lebih dengan rumus koefisien korelasi produk moment yaitu menentukan Koefisien Determinasi $\left(\mathrm{R}^{2}\right)$ dan Uji Signifikansi dengan pendekatan Uji-t

\section{HASIL DAN PEMBAHASAN}

Dari hasil uji coba validitas instrumen penelitian diperoleh kesimpulan bahwa untuk 21 item butir angket tersebut dinyatakan valid, dan untuk 19 item butir angket tersebut dinyatakan tidak valid, untuk dalam pembuatan instrumen penulis mengambil 20 butir angket yang valid, karena untuk menyeimbangkan antara angket positif dan negatif, sehingga dapat dipergunakan untuk penelitian yang akan dijadikan sebagai data untuk kelas penelitian pada pengujian teknik analisis data berikutnya. Setelah instrumen 
dilakukan uji coba dan diperoleh hasil analisis datanya valid, maka dilakukan pengujian berikutnya yaitu reliabilitas untuk mengetahui ketepatan suatu data.

Setelah melakukan uji validitas, penulis melanjutkan dengan uji reliabilitas dengan hanya menghitung reliabilitas butir angket yang valid, sementara yang tidak valid tidak dihitung relibilitasnya. Adapun butir angket yang valid adalah sebanyak 20 butir soal, sehingga yang akan di reliabilitaskan hanyalah angket yang valid sebanyak 20 butir. Lebih lanjut analisis Uji reliabilitas intrumen angket menggunakan rumus Alpha Cronbach yakni menghitung varians skor tiap-tiap item.

Hasil uji yang dilakukan dengan 30 orang siswa dengan tingkat signifikansi 5\% dan $\alpha$ derajat kebebasan (df) $\mathrm{n}-2$ atau 30-2 $=28, \mathrm{r}$ tabel sebesar 0,374 sedangkan $\mathrm{r}_{\text {hitung }}$ sebesar 0,863 sehingga $r_{\text {hitung }}>r_{\text {tabel }}$, maka dapat disimpulkan bahwa angket reliabel, dan jika diujikan beberapa kali maka hasil tetap konsisten atau hasilnya tetap sama. Selanjutnya dilakukan sebaran angket pada sebanyak 124 orang siswa yang terdiri dari seluruh siswa kelas VII MTs sebagai responden dalam jangka waktu dua kali pertemuan. Kemudian dianalisis diskriptif hasil penelitian dari angket konsep diri siswa, yakni mean, median, dan modus dalam bentuk diagram atau gambar.

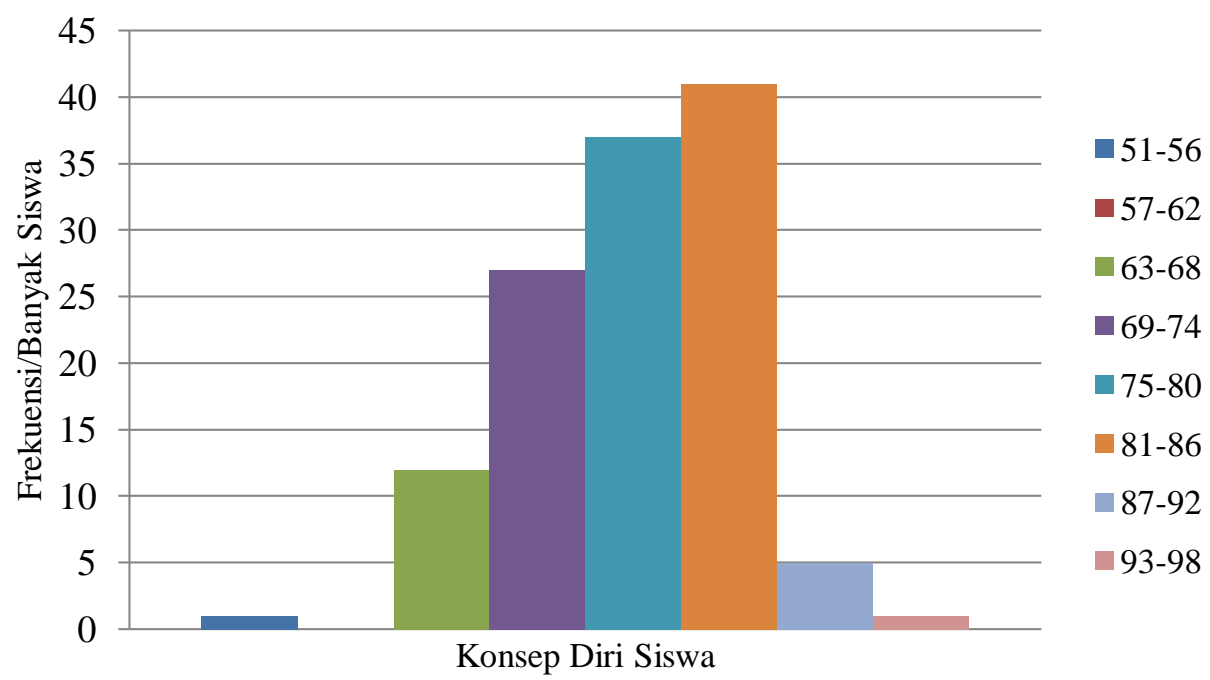

Gambar 1. Diagram Konsep Diri Siswa 


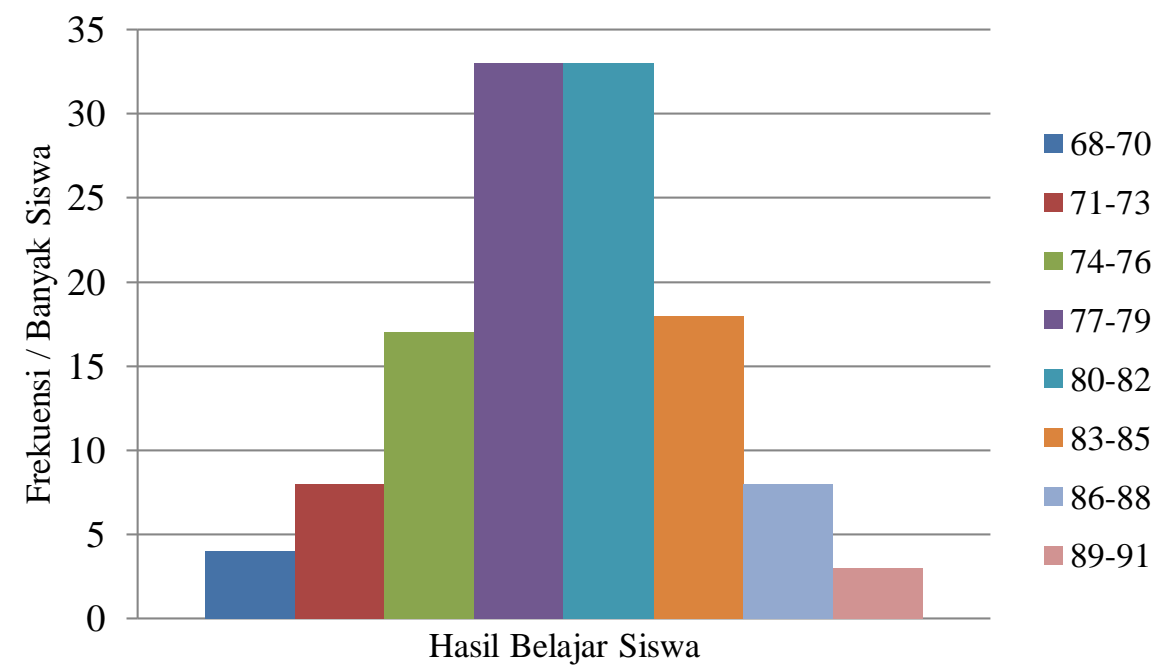

Gambar 2. Diagram Hasil Belajar Siswa

Berdasarkan Data hasil belajar Biologi siswa sesuai dengan berdasarkan KKM maka dinyatakan bahwa siswa yang tuntas sebanyak 119 orang siswa dan siswa yang tidak tuntas sebanyak 5 orang siswa. Hasil belajar biologi siswa menghasilkan persentase Ketuntasan Belajar mata pelajaran Biologi siswa adalah 96\%, dan kemudian data hasil belajar tersebut dinormalitaskan. Untuk pengujian normalitas digunakan dengan Chi kuadrat, sebelumnya jumlah kelas interval ditetapkan $=6$. Hal ini sesuai dengan 6 bidang yang ada pada Kurva Normal Baku, selanjutnya menentukan panjang kelas interval serta menyusun kedalam tabel distribusi frekuensi, sekaligus tabel penolong untuk menghitung harga Chi Kuadrat hitung. Frekuensi yang diharapkan $\left(f_{h}\right)$ diperoleh dari persentasi luas tiap bidang kurva normal dikalikan jumlah data observasi (jumlah individu sampel), sehingga dalam perhitungan ditemukan Chi kuadrat hitung $=4,73$ selanjutnya harga Chi Kuadrat hitung dibandingkan dengan harga Chi Kuadrat tabel dengan dk (derajat kebebasan) $=6-1=5$ adalah 11,070, jadi Chi Kuadrat tabel $>$ Chi Kuadrat hitung maka data nilai statistik berdistribusi normal. 


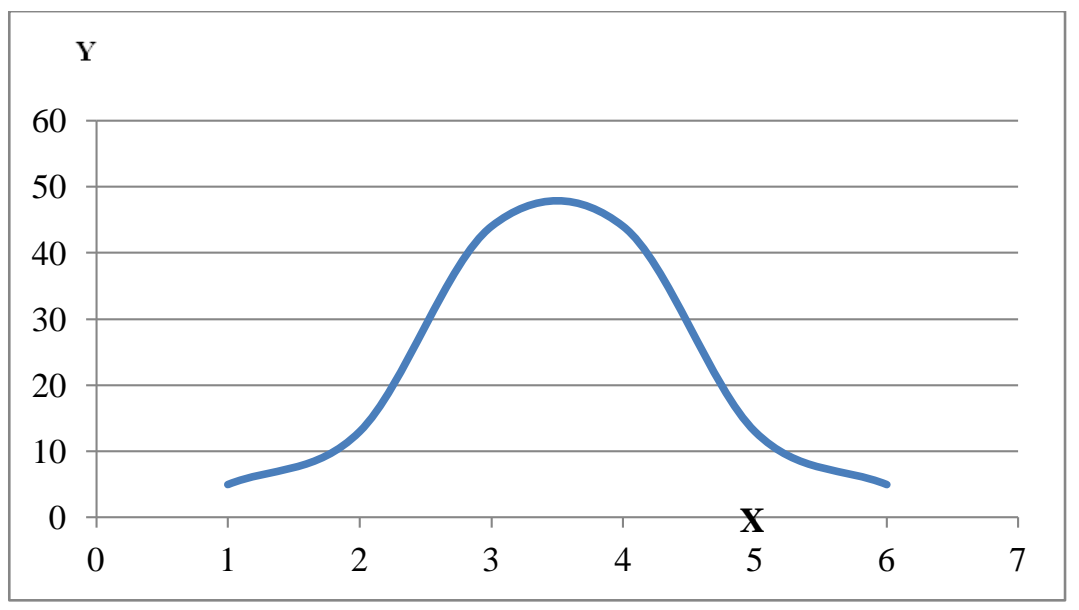

Gambar 3. Kurva Distribusi Normal Nilai Statistik Hasil Belajar Biologi Siswa

Hasil analisis korelasi hubungan konsep diri terhadap hasil belajar biologi siswa tergolong rendah yakni 0,246 (24,6\%), artinya tidak terdapat korelasi antara konsep diri dengan hasil belajar. Sedangkan uji lanjut yaitu uji $\mathrm{t}$ (signifikan) menunjukkan $\mathrm{t}_{\text {hitung }} 2,890$ $>t_{\text {tabel }} 1,960$ sehingga $H_{o}$ tolak terima $H_{i}$, berarti memang tidak ada hubungan yang signifikan atau sangat berbeda antara nilai konsep diri dengan hasil belajar dengan nilai koefisien determinasi $\left(\mathrm{R}^{2}\right)$ sangat kecil yaitu 0,060516 atau 6,05\%. Dengan demikian terbukti bahwa konsep diri siswa tidak memiliki hubungan signifikan dengan hasil belajar biologi siswa kelas VII MTs Unit Sekolah Baru Sagulung Batam. Sebagai bukti tersebut tidak ada hubungan dapat dilihat pada nilai koefisien determinasi (KD) hanya 6,05\% artinya faktor nilai konsep diri sangat kecil memberikan pengaruh dibandingkan faktor lainnya yang tidak diketahui sebesar 93,05\%.

\section{KESIMPULAN}

Berdasarkan data yang diperoleh dan dari hasil analisis yang dilakukan maka dapat ditarik kesimpulan bahwa tidak terdapat hubungan positif dan signifikan antara konsep diri dengan hasil belajar Biologi siswa kelas VII MTs Unit Sekolah Baru Sagulung Batam. Kekuatan hubungan tersebut ditunjukkan melaui koefisien korelasi sebesar 24,6\% dan nilai koefisien determinasi sebesar $6,05 \%$ sangat kecil kontribusinya tentang konsep diri terhadap hasil belajar.

\section{REFERENSI}

Arikunto, S. 2010. Prosedur Penelitian Suatu Pendekatan Praktek. Rineka Cipta. Jakarta. 
Budiyarti, Y. 2011. Minat Belajar Siswa Terhadap Mata Pelajaran Bahasa Indonesia. UIN Syarif Hidayatullah. Jakarta.

Daryanto, 2013.Inovasi Pembelajaran Efektif, Yrama Widya. Bandung.

Ivonyerniwaty, (2011). Aktivitas dan Pengalaman Belajar. http://ivonyerniwaty. wordpress.com/aktivitas-dan-pengalaman belajar/. Diakses 27 Maret 2014

Mukhtar. 2013. Metode Praktis penelitian Deskriptif Kualitatif. Referensi GP Press Group. Jakarta.

Sardiman, 2009. Interaksi dan Motivasi Belajar Mengajar, Rajawali. Jakarta.

Slameto, (2010), Belajar dan factor-faktor yang mempengaruhinya. Rineka Cipta. Jakarta. 